\title{
The isoenzyme pattern: Some comparative-biochemical and developmental aspects
}

\author{
Hugo Aebi, Roland Richterich \\ and Jean-Pierre von Wartburg \\ Medizinisch-chemisches Institut der Universität Bern, Schweiz
}

\begin{abstract}
KURZFASSUNG: Das Isoenzymmuster: Einige vergleichend-biochemische und entwicklungsgeschichtliche Aspekte. Zunächst für einheitlich gehaltene Enzyme sind in zunehmender Zahl aus verschiedenen Isoenzymen bestehend erkannt worden. Diese lassen sich auf Grund ihrer unterschiedlichen elektrophoretischen Beweglichkeit auftrennen. Das Isoenzymmuster eines Organs hängt ab von (1) der Art der beteiligten Gewebe, (2) dem Differenzierungsgrad und (3) der Spezies. Zwei Beispiele werden behandelt: Kreatinkinase (E.C. 2.7.3.2.) und Alkoholdehydrogenase (E.C. 1.1.1.1.). In den Geweben des Säugers kommen 3 Kreatinkinase-Isoenzyme vor. Während im Gehirn ausschließlich der rasch wandernde Typ I vorkommt, enthält Skelettmuskulatur der adulten Ratte ausschließlich den langsam wandernden Typ III. Im Verlauf der Entwicklung erfährt das Isoenzymmuster des Skelettmuskels typische, phasenweise ablaufende Veränderungen. Im frühen Stadium der Embryonalentwicklung ist ausschließlich Typ I zu finden; bei der Geburt kommen alle 3 Typen gleichzeitig vor, wogegen bei alten Ratten nur noch Typ III vorhanden ist. Eine analoge Altersabhängigkeit ist auch beim Hühnerküken zu beobachten; diese Veränderungen laufen hier jedoch wesentlich rascher ab. Die Leberalkoholdehydrogenase besteht je nach Herkunft aus einer verschiedenen Anzahl Isoenzymen. Das Enzym aus der Leber des Menschen läßt sich mittels Agargelelektrophorese in 3 Banden aufteilen; Rhesusaffenleber enthält 2, Pferdeleber 5 Isoenzyme. Beim Rhesusaffen findet sid zudem ein drittes Isoenzym in anderen Organen. Die gereinigten Isoenzyme II und III aus Rhesusaffenleber unterscheiden sich in bezug auf verschiedene kinetische Parameter. Eine atypische Alkoholdehydrogenase wurde beim Menschen gefunden. Sie zeichnet sich gegenüber dem normalen Enzym durch eine hohe spezifische Aktivität sowie durch Unterschiede im pH-Optimum und in der Substratspezifität aus.
\end{abstract}

\section{INTRODUCTION}

An increasing number of enzymes have been found to occur in multiple molecular forms, so-called isoenzymes. They differ slightly in their physico-chemical properties and, therefore, can be separated into various fractions by electrophoresis and other suitable methods. Isoenzymes, according to the definition adopted, occur simultaneously within the same species or even in the same cellular compartment (AEBI \& RICHTERICH 1963).

Enzyme heterogeneity is of considerable interest to the biologist, because it offers some insight into an additional regulatory mechanism of the cell to achieve the highest 
possible degree of adaptation between the enzyme on one hand and the specific metabolic requirements on the other. Every tissue has its characteristic enzyme pattern. This is also true for the isoenzymes. The isoenzyme pattern of an organ depends on (1) the nature of the participating tissue components, (2) the degree of differentiation and (3) the species. Most studies have been made on lactate dehydrogenase so far. This communication deals with some findings on the isoenzymes of creatine-kinase (ATPCreatine-Phosphotransferase; E. C. 2.7.3.2.) and of alcohol dehydrogenase (E. C. 1.1.1.1.).

\section{RESULTS}

In mammalian tissues three different isoenzymes of creatine kinase can be distinguished (BURgER, Richterich \& AEBI 1964). Separation is obtained by agar gel electrophoresis. Identification of enzyme activity is based on the coupled optical test, i. e. by the disappearance of the fluorescence of $\mathrm{NADH}_{2}$ under ultraviolet illumination. In

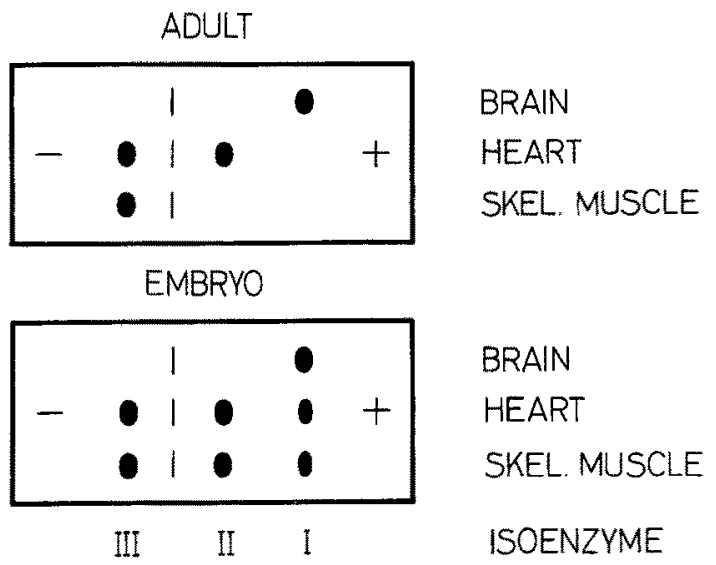

Fig. 1: Isoenzyme pattern of creatine kinase activity in various organs of the adult rat and the rat embryo. Separation technique: Agar gel electrophoresis, as described by EPPENBERGER et al. (1964)

Figure 1 the isoenzyme pattern of adult skeletal muscle, cardiac muscle and brain of the rat are shown. In skeletal muscle isoenzyme $\mathrm{II}$, migrating at $\mathrm{pH} 8$ slowly to the cathode (due to endosmosis) is predominant. Traces of isoenzymes II are occasionally seen, but isoenzyme $I$ is always missing. Nonspecific reactions (blank: incubation of slides without creatine) are very weak and restricted to the application slot. In cardiac muscle all three isoenzymes are present, increasing in activity from isoenzyme $I$ to isoenzyme III. In brain isoenzyme I, migrating relatively fast to the anode, predominates. The isoenzyme pattern at early embryonic stages is completely different from the adult pattern in skeletal and heart muscle, but there is no change in the isoenzyme pattern of the brain. The shift from the embryonic to the adult pattern proceeds relatively fast in the skeletal muscle of the chick; in rat skeletal muscle, however, this change covers almost the whole life span. 
The development of creatine kinase isoenzymes in rat skeletal muscle can be seen in Figure 2: Up to a fetal age of 11 days ( -8 to -10 days considered from the day of birth) isoenzyme $I$ is present exclusively. Two days later traces of isoenzyme II appear, and on the 18 th day ( 3 days before birth) isoenzyme III appears. Activity shifts continuously from band I to band III, so that at the parturition stage band III is predominant, band II intermediate and isoenzyme I weak. The shift continues after birth, so that at the age of 90 days band I has disappeared completely, and in very old rats

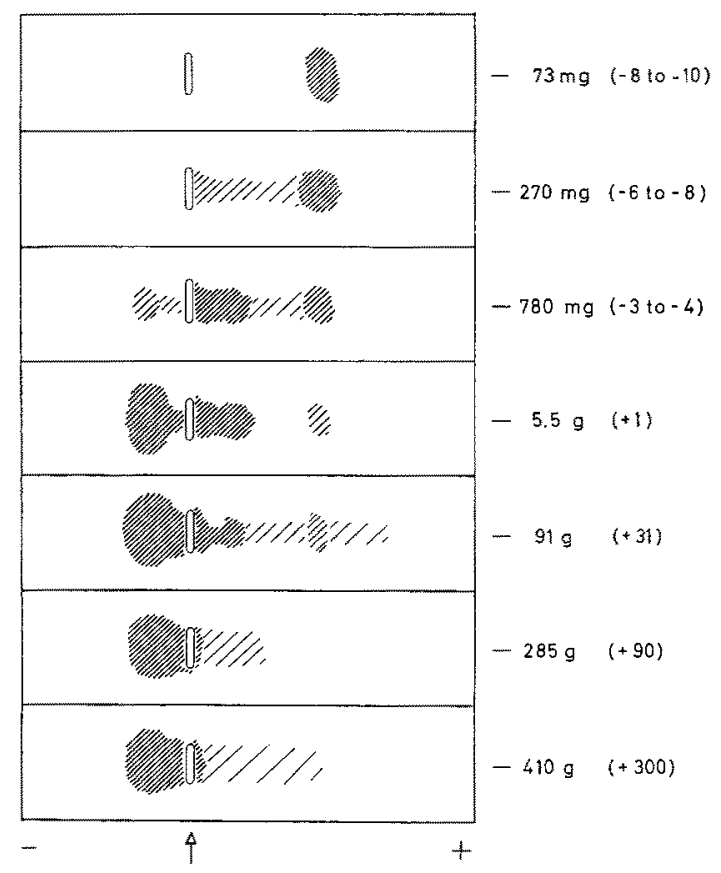

Fig. 2: Creatine kinase isoenzyme of rat skeletal muscle. Weight of embryo in milligrams, or animal in grams. In parentheses, age of embryo (parturition $=0$ ) or animal in days. (After EPPENBERGER et al. 1964)

(300 days) isoenzyme II is disappearing too. Consequently there is a complete shift in the isoenzyme pattern of creatine kinase in muscle tissue. It is of interest to correlate morphological, functional and other biochemical findings with the observations mentioned above. This has been done by EPPENBERgER et al. (1964) for chicken skeletal muscle.

Since it has been shown, that the creatine kinase molecule is a dimer, the observation of three different creatine kinase isoenzymes fits the hypothesis of KAPLAN and his group (CAHN et al. 1962) and Appella \& MarkerT (1961). These authors explained the existence of 5 different lactate dehydrogenase isoenzymes by a mechanism shown in Figure 3. Accordingly, the active enzyme is composed of four enzymatically inactive subunits of two different types. A similar mechanism may be postulated for creatine kinase: Two monomers $\mathrm{B}(=$ brain $)$ and $\mathrm{M}(=$ muscle $)$ may be formed under 
genetic control and may combine at random to form three isoenzymes $\mathrm{BB}, \mathrm{BM}$ and MM.

Alcohol dehydrogenase, the second enzyme to be discussed here, also exists in multiple molecular forms. So far, isoenzymes have been detected in human and horse liver

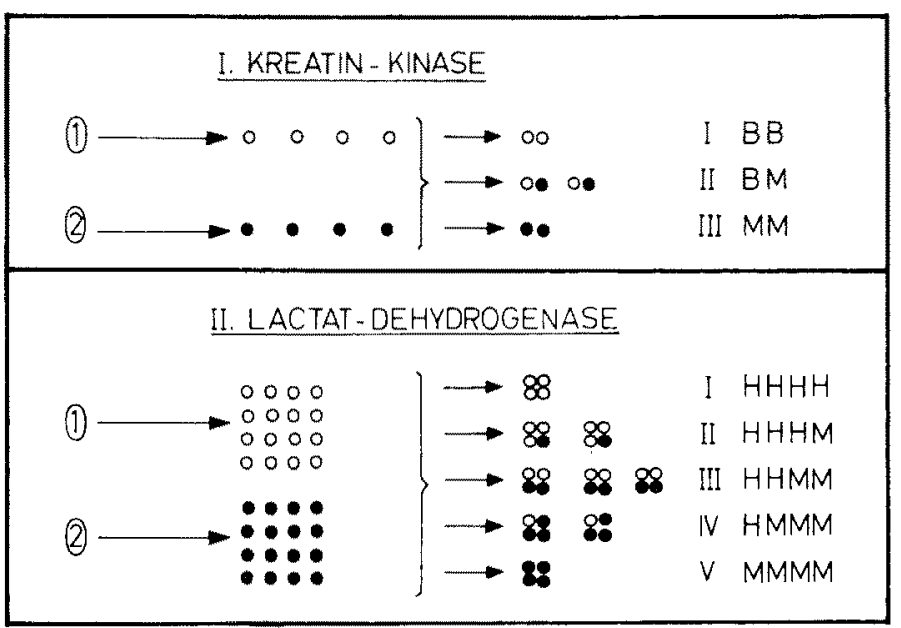

Fig. 3: Hypothesis of Appelia \& Markert (1961) and of CaHN et al. (1962) on the mechanism of isoenzyme formation in lactate dehydrogenase. Analogous proposal for creatine kinase. (After AEBi \& Richterich 1963)
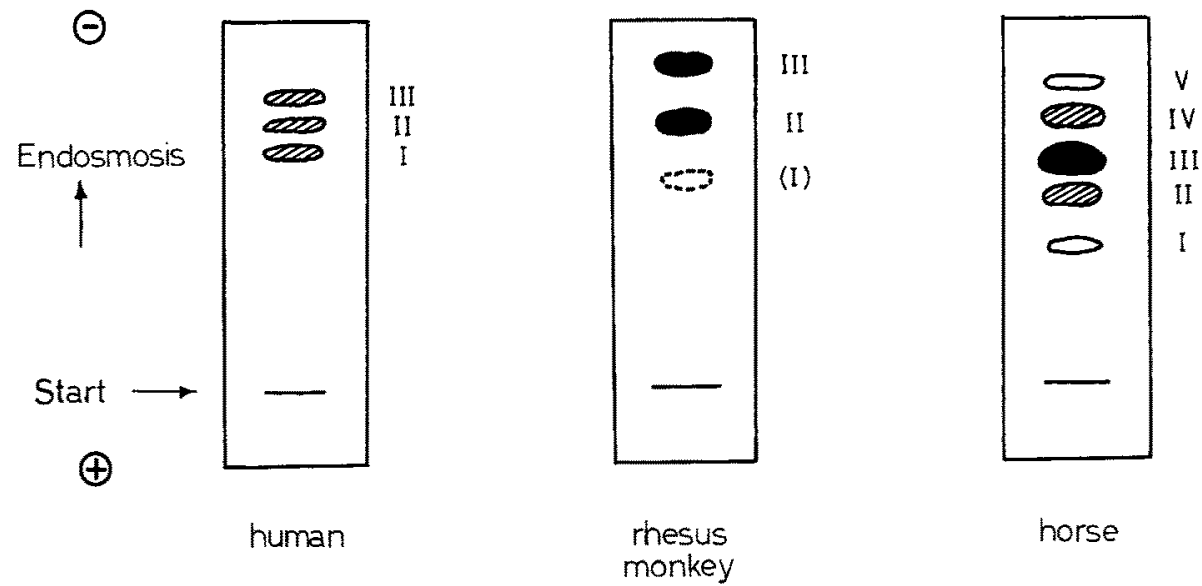

Fig. 4: Alcohol dehydrogenase isoenzymes in the liver of different species. Separation by agar gel electrophoresis (VON WARTBURG, in preparation)

as well as in various organs of the rhesus monkey. The isoenzyme pattern in the liver of these three species is demonstrated in Figure 4. There are three bands in liver tissue of man, only two in liver of Macacus rhesus, whereas 5 different fractions can be distinguished in horse liver. In the liver of the rhesus monkey $\mathrm{ADH}$-activity is about equally 
distributed in fraction I and II. These fractions can be separated either by agar gel electrophoresis or by chromatography on carboxymethyl cellulose. The different electrophoretic mobility of the two fractions remains unchanged after separation and purification of the isoenzymes. A third isoenzyme is found in other organs such as the lungs, the bladder and in particular the whole gastrointestinal tract (Fig. 5).

The isoenzymes present in the liver of Macacus rhesus also differ in respect to their kinetic properties, such as the rates of alcohol oxidation as compared to the aldehyde reduction. Isoenzyme III reduces acetaldehyde 25 times faster than it oxidizes

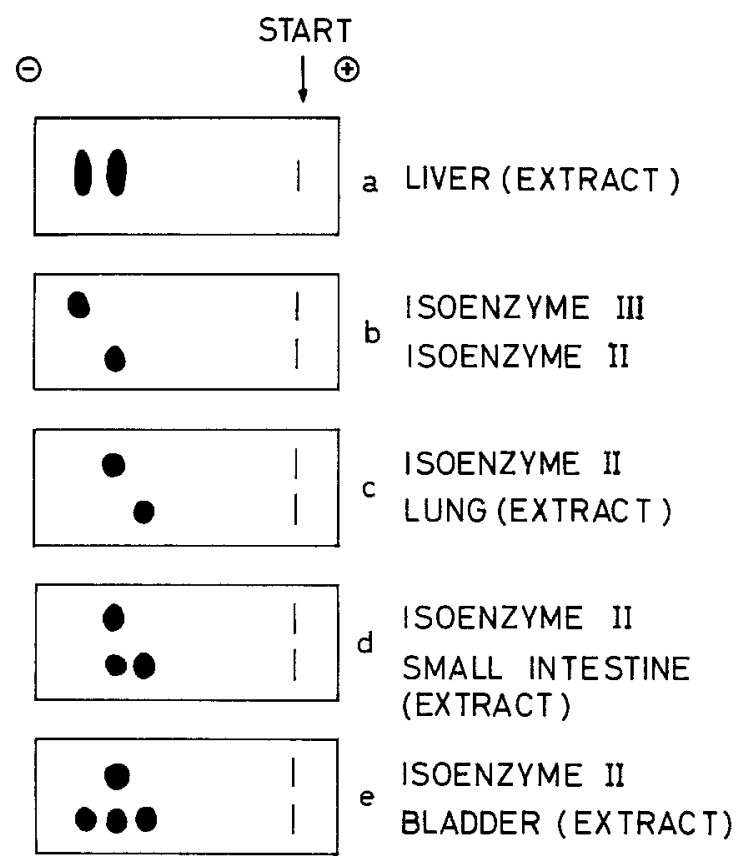

Fig. 5: Alcohol dehydrogenase isoenzymes in different organs of Macacus rhesus. Separation by agar gel electrophoresis. (After Papenberg, voN Wartburg \& Aebi 1965)

ethanol under given experimental conditions. This ratio is only 8 for isoenzyme II under the same conditions. Both isoenzymes are inhibited by metal-chelating agents (e. g. o-phenanthroline) and activated by thiourea; there are, however, quantitative differences. The substrate specificity of both isoenzymes towards a series of homologous alcohols and aldehydes also shows marked differences. Thus, isoenzyme II has a distinctly higher affinity than isoenzyme III for homologues, such as n-butanol, n-octanol as well as for benzyl alcohol and cyclohexanol.

Similar studies on the heterogeneity of alcohol dehydrogenase in human liver have led to the detection of two human subjects with an extremely high alcohol dehydrogenase activity (vON WARTBURG et al. 1965). In one case the liver as a whole contained 16000 international enzyme units measured under standard conditions $(\mathrm{pH}=8.8$; $[\mathrm{S}]=1.6 \cdot 10^{-2} \mathrm{M}$ ethanol). This figure is about 6 times above normal. Further investi- 
gations have shown that this high activity is due to the existence of an atypical alcohol dehydrogenase. This anomalous enzyme, in purified form, differs from normal human liver alcohol dehydrogenase in several aspects: The most significant difference is observed in the $\mathrm{pH}$ rate profiles (Fig. 6). In contrast to the $\mathrm{pH}$-optimum of normal alcohol dehydrogenase $(\mathrm{pH} 10.8)$, maximum rate of ethanol oxidation with the variant enzyme occurs at $\mathrm{pH} 8.5$. Therefore, since the forward reaction is measured at $\mathrm{pH} 8.8$ (= stan-

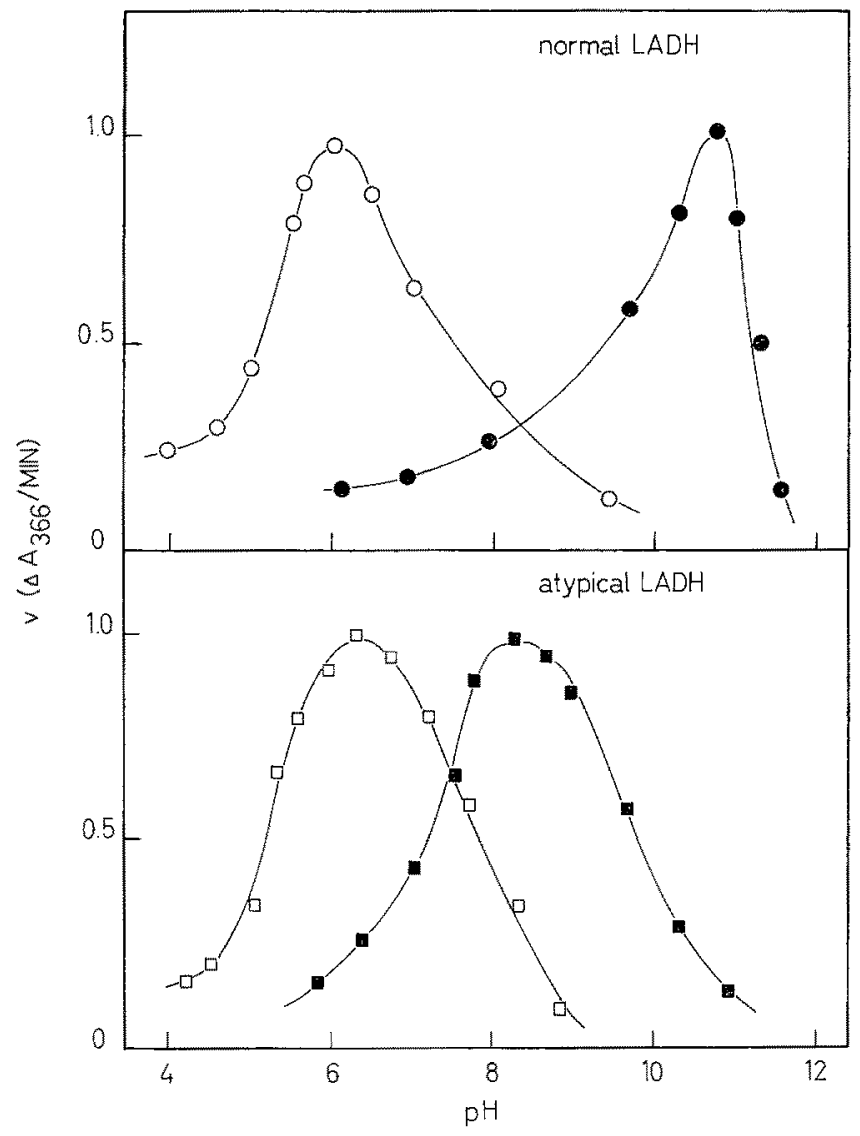

Fig. 6: pH-dependence of ethanol oxidation $(\bullet, \mathbf{a})$ and acetaldehyde reduction $(O, \square)$ for atypical ( = square figures) and for normal (= circles) human liver alcohol dehydrogenase. (After von Wartburg, Papenberg \& Aebr 1965)

dard assay condition), this is an environment offering far better conditions for the atypical enzyme than for the normal. Furthermore, these enzymes differ in regard to substrate specificity. The oxidation of the higher homologues of ethanol, of isopropanol, benzyl alcohol and cyclohexanol is absolutely and relatively faster in presence of the atypical enzyme.

Enzymatic activity of normal human, rhesus monkey and horse liver-ADH is enhanced when thiourea is added to the assay mixture. Under these conditions, how- 
ever, the atypical human liver-ADH (and similarly yeast-ADH) is inhibited, but these effects can only be observed with the purified enzymes and not in crude homogenates. Nevertheless, this property can be used, together with the differences in the pH rate profile, to recognize the atypical enzyme in small samples of liver tissue (screening test). The functional significance of this variant $\mathrm{ADH}$ for ethanol metabolism remains to be elucidated. Several possibilities are conceivable; e. g. a carrier of this anomaly may have a correspondingly high capacity to oxidize ethanol; but it is possible that another factor becomes rate limiting.

\section{DISCUSSION}

What are the implications of these findings for quantitative biology? Even if the activity of an enzyme is measured under standard conditions, there is no guarantee that the figures obtained from such determinations represent "pure parameters" as other quantitative data. The biologist has to verify first, whether the activity he has measured is the expression of a single enzymatic entity or if it must be considered as the sum (or resultant) of a variety of effects. Therefore, the analysis of an enzyme for heterogeneity is a prerequisite, in order to get a clearcut answer in this respect. This recommendation for any work in the field of quantitative biology is of practical importance, because the number of enzymes shown to be heterogenous in composition, is growing rapidly (WILKINSON 1965). Either example given in this report offers enough evidence that a detailed qualitative study must be the base for any quantitative approach in enzymology, such as the evaluation of changes during fetal development or of differences between various organs or species.

Furthermore, quantitative studies, which are usually performed on a population of considerable size, offer a good opportunity to detect "new" anomalies. There are quite a few examples in literature demonstrating the efficiency of screening procedures in order to spot carriers of rare (or hitherto unknown) enzyme defects. Aberrant figures should never be discarded or eliminated, but should always be a reason to check this individual carefully. It may be, that it contains an unusual amount of normal enzyme or carries an anomalous enzyme of unusual properties.

There is no doubt, that with these possibilities in mind the study of enzyme and isoenzyme patterns can be a challenging and promising topic in the vast field of quantitative biology.

\section{SUMMARY}

1. In mammalian tissues three different isoenzymes of creatine kinase can be distinguished. Whereas in brain tissue exclusively type I is found, muscle tissue of the adult rat containes type III only. In ontogeny, however, typical changes in the isoenzyme pattern of skeletal muscle can be observed: In early embryonic stages only type I is found; at birth all three are present. This heterogenous pattern gradually changes to the adult pattern exclusively consisting of isoenzyme III. 
2. Alcohol dehydrogenase from liver of horse, Macacus rhesus and of man also consists of several isoenzymes. They can be separated by agar gel electrophoresis or chromatography on CM-cellulose. There are three bands in liver tissue of man, only 2 in liver of Macacus rhesus, whereas 5 different fractions can be distinguished in horse liver.

3. In two out of 30 human livers analyzed so far, an atypical enzyme with different kinetic properties has been detected.

\section{LITERATURE CITED}

Aeri, H. \& Richterich, R., 1963. Aktuelles zur Biologie der Enzyme. Helv. med. Acta 30, 353-390.

Aprella, E. \& Markert, C. L., 1961. Dissociation of lactate dehydrogenase into subunits with guanidin hydrochloride. Biochem. biophys. Res. Commun. 6, 171.

Burger, A., Richterich, R. \& AEBi, H., 1964. Die Heterogenität der Kreatinkinase. Biochem. Z. 339, 305-314.

Cain, R. D., Kaplan, N. O., Levine, L. \& Zwilling, E., 1962. Nature and development of lactic dehydrogenases. Science, N.Y. 136, 962.

Eppenberger, H. M., Fellenberg, R. von, Richterich, R. \& Aebi, H., 1962/63. Die Ontogenese von zytoplasmatischen Enzymen beim Hühnerembryo. Enzymologia biol. clin. 2, $139-174$.

- Eppenderger, M., Richterich, R. \& Aebi, H., 1964. The ontogeny of creatine kinase isoenzymes. Devl. Biol. 10, 1-16.

Papengerg, J., Wartburg, J.P. von \& Aebr, H., 1965. Die Heterogenität der Alkoholdehydrogenase aus Rhesusaffenleber. Biochem. Z. 342, 95-107.

Wartburg, J. P. von, PApenberg, J. \& Aebi, H., 1965. An atypical human alcohol dehydrogenase. Can. J. Biochem. Physiol. 43, 889-898.

- 1966. Ms. (in preparation).

WILKInson, J. H., 1965. Isoenzymes. Spon, London, 158 pp.

\section{Discussion following the paper by AEBI, RICHTERICH \& v. WARTBURG}

Hess: Wie Sie wissen, besteht der Unterschied zwischen Hefe-ADH und Leber-ADH in der strengen Substratspeziftüt der Hefe-ADH gegenüber Athylalkohol und Acetaldehyd im Gegensatz zu der bisher bekannten substrat-unspezifischen Leber-ADH. Findet man nun in Threr Leber-ADH I eine der Hefe-ADH vergleichbare Substratspezifität?

AEBr: Zwischen $A D H$ aus Hefe und Säugerleber bestehen Unterschiede in der Strukrur, wie zum Beispiel im Molekulargewidht, oder in der Dissoziierbarkeit in Untereinheiten. Es bestehen auch Unterschiede in den katalytischen Eigenschaften, vor allem in der Wechselzahl, der Art der schrittbegrenzenden Umsetzung sowie in der Spezifität bezüglich Substrat und Coenzym. Die beträchtlichen Unterschiede hinsichtlich Substratspezifität sind indessen mehr quantitativer als qualitativer Art. Da die Abklärung der Substratspezifität meist nur bei einer einzigen Substratkonzentration durchgeführt zu werden pflegt, sind die entsprechenden Resultate nicht ohne weiteres mit den hier mitgeteilten Befunden vergleichbar, indem hier ein Konzentrationsbereich von 5 Dekaden erfaßt worden ist. In bezug auf die langsamere Umsetzung von Isopropanol, Cyclohexanol und Benzylalkohol durch die Leber-ADH I des Rhesusaffen scheint in der Tat eine gewisse Analogie zum Hefeenzym zu bestehen, und zwar sofern die getesteten Alkohole als repräsentative Vertreter der verschiedenen Alkoholtypen gewertet werden dürfen. 
Hess: Sie bringen hier zwei Isoenzyme. Man hat den Eindruck, daß die Natur für dieselbe Reaktion zwei Enzyme benutzt, wobei das eine bevorzugt in der einen, das andere in der entgegengesetzten Richtung arbeitet. Habe ich Sie richtig verstanden?

AEBI: Der Spezifitätsunterschied zwischen ADH-I und ADH-II aus Leber triff sowohl für die Vorwärts- als anch für die Rückwärts-Reaktion zu. ADH-I oxydiert bevorzugt Äthanol beziehungsweise reduziert bevorzugt Acetaldehyd; ADH-II oxydiert bevorzugt Fuselalkohole beziehungsweise reduziert bevorzugt die entsprechenden Aldehyde.

MnLer: Are your findings on the substrate specificity of alcohol dehydrogenase consistent with the classical definition of isoenzymes?

AEBI: I would say yes. 